\title{
TREATMENT TRAILS FOR EQUINE VIRAL ABORTION BY USING NATURAL COMPOUND IN VITRO
}

\author{
HASSAN Y.A.H. MAHMOUD ${ }^{1}$ and MOSTAFA ABDELRAHMAN ${ }^{2}$ \\ ${ }^{1}$ Division of Infectious Diseases, Animal Medicine Department, Faculty of Veterinary Medicine, South \\ Valley University, Qena 83523. \\ ${ }^{2}$ Botany Department Faculty of Science, Aswan University, Aswan 81528, Egypt
}

Received: 31 March 2018; Accepted: 31 April 2018

\begin{abstract}
Equine herpesvirus 1 (EHV-1), infections is found in horse populaces worldwide and cause a febrile respiratory ailment every year among foals in zones with concentrated steed populaces, the result of infection is dictated by viral strain, resistant, pregnancy status and potentially age, disease of pregnant mares with EHV-1, may abort after weeks to months by clinical or subclinical infection. Treatment of viral infection in animals it appears to be exceptionally troublesome and require a considerable measure of cost, in the present investigation, we used a steroidal saponin compound from dry roots of shallot, the infection rate of EHV-1 in vitro was detected by neutralization test and flowcytometric analysis, the result of infection rate was decreased after 24 hour by 55.7 $59.2 \%$ when added saponin with concentration of $50 \mu \mathrm{g}-100 \mu \mathrm{g}$, this natural compound may be used as effective materials for treatment animals against viral infection.
\end{abstract}

Key word: EHV-1, antivirus

\section{INTRODUCTION}

Horses can get EHV-1 infection by inhalation of infectious aerosols or direct contact with infectious secretions (Allen and Bryans, 1986). The virus attaches and replicates in the epithelium of the upper respiratory tract, including the nose, turbinate, pharynx, soft palate and trachea (Patel et al., 1982; Kydd et al., 1994). Subsequently, the virus penetrates the basement membrane and disseminates into the stroma, thereby infecting mononuclear cells and endothelial cells of local blood vessels (Edington et al., 1986; Kydd et al., 1994). Replication in the respiratory tract can be extensive and is accompanied by erosions with vesiculation of the mucosa and thrombosis (Kydd et al., 1994). Infected steeds shed a lot of infection into the environment, nasal shedding is seen from day one up till two weeks after infection (Gibson et al., 1992; Heldens et al., 2001; van der Meulen et al., 2006). EHV-1 and 4 were considered as two subtypes of the same virus namely EHV-1, the separation amongst EHV-1 and 4 came after their genomic DNA were analyzed (Turtinen et al., 1981; Sabine et al., 1981; Studdert et al., 1981).

Corresponding author: Dr. HASSAN Y.A.H. MAHMOUD E-mail address: hayvet2002@yahoo.com

Present address: Division of Infectious Diseases, Animal Medicine Department, Faculty of Veterinary Medicine, South Valley University, Qena 83523.
Today in many cases numerous viruses stay without powerful vaccination and just of few antiviral medications is authorized for clinical practice, consequently there is a critical need to find an antiviral that are profoundly effectual and financially savvy for the administration and control of viral contaminations when antibodies and standard treatments are deficient (Liang et al., 2014).

Herbs have been utilized as a part of society pharmaceutical since numerous years and the utilization of home grown inferred common items as a remedial device has been expanding extensively (Slader et al., 2006; Eisenberg et al., 2001).

The Allium genus is one of the essential monocytic genera containing more than 850 species that expand broadly finished the northern portion of the globe from the boreal zone to the dry subtropics (Kamenetsky and Rabinowitch, 2006; Fritsch et al., 2010). Various sorts of this genus, for instance, $A$. cepa (onion), A. cepa Aggregatum gathering (shallot), A. sativum (garlic), A. fistulosum (Japanese grouping onion) and $A$. ampeloprasum (leek), have been used as a piece of food planning and society pharmaceutical for long time (Mostafa et al., 2013). Onion use as a food settling or ethnomedicine is generally credited to its dietary and helpful properties, including antiasthmatic, anticholesterolemic and antimicrobial properties 
(Caruso et al., 2014; Abdelrahman et al., 2014, 2016). Until now there is no immunization can be complete protect the horse against EHV-1, although primary and recurrent infections are very difficult to control in horse worldwide.

\section{MATERIALS AND METHODS}

\section{Cells}

FHK-Tcl3.1 (Maeda et al., 2007; Andoh et al., 2009) cells were kept up in Dulbecco's Modified Eagle's Medium (DMEM) (Gibco, Invitrogen) supplemented with $10 \%$ heat-inactivated fetal calf serum (FCS) and 100 unit of penicillin and $100 \mu \mathrm{g}$ of streptomycin (Gibco, Invitrogen) per $\mathrm{ml}$ and incubation at $37^{\circ} \mathrm{C}$ with $5 \% \mathrm{CO}_{2}$.

\section{Viruses}

EHV-1 strain 89c25 was isolated from a racehorse with respiratory diseases in the epizootic of EHV-1 respiratory infection (Matsumura et al., 1992), EHV1 strain $89 \mathrm{c} 25$ was plaque-purified three times in primary fetal horse kidney (FHK) cells and termed as $89 \mathrm{c} 25 \mathrm{p}$. Virus was released by three cycles of solidifying and defrosting. The harvested culture fluids were clarified by centrifugation at $3500 \mathrm{rpm}$ for $15 \mathrm{~min}$ at $4{ }^{\circ} \mathrm{C}$ to remove cell debris and stored at $80^{\circ} \mathrm{C}$. Viral infectivity was measured by plaque assay.

\section{Saponin compound}

The extraction and segregation of the unadulterated saponin compound named Cepa2, from shallot dry roots (40 g) was performed by the method of (Mostafa et al., 2013). The characterizing of this compound with it is ability as anticancer activity in vitor was done by (Mostafa et al., 2017).

\section{Virus infection}

Saponin compound with concentration $(50-100 \mu \mathrm{g})$ or medium alone (control) were mixed with equal volume of virus solution containing $50 \mathrm{PFU} / 100 \mu \ell$, incubated at $37^{\circ} \mathrm{C}$ for $1 \mathrm{hr}$ and then the mixtures were added to FHK-Tcl3.1 cells, after incubation for 60 min at $37{ }^{\circ} \mathrm{C}$ in $5 \% \mathrm{CO}_{2}$, the cells were washed twice with DMEM and overlaid with $0.8 \%$ agarose (Sea Plaque GTG agarose, Lonza) in DMEM containing $10 \%$ FCS. The plates were then incubated at $37{ }^{\circ} \mathrm{C}$ in $5 \% \mathrm{CO}_{2}$ for one day. The cells were settled with $5 \%$ buffered formaldehyde for $1 \mathrm{hr}$ and the agarose layers were expelled and staining with crystal violet and plaques were checked.

\section{Flowcytometric analysis}

The infected and control cells were harvested in phosphate buffer solution on ice then the cells were washed three times and resuspended in flowcytometric analysis buffer $(1 \mathrm{x}$ PBS $+2 \%$ fetal calf serum $+0.1 \%$ sodium azide in PBS) discard the supernatant, vortex and centrifuge at $2000 \mathrm{rpm}$ for 2 minutes at $4{ }^{\circ} \mathrm{C}$ and then incubated with monoclonal antibody specific to EHV-1(Mahmoud et al., 2013) diluted to (1:500) for $20 \mathrm{~min}$ at $4^{\circ} \mathrm{C}$, after three times washed cells with flowcytometric analysis buffer, cells were incubated with Alexa Fluor ${ }^{\circledR} 488$ goat anti-mouse $\operatorname{IgG}(\mathrm{H}+\mathrm{L})$ (Invitrogen) for $20 \mathrm{~min}$ at $4{ }^{\circ} \mathrm{C}$ and then washed three times with flowcytometric analysis buffer (McSharry, J.J., 1994; Huang et al., 2005). Cells were suspended in flowcytometric analysis buffer and then analyzed by the flow cytometer software (BD Accuri ${ }^{\mathrm{TM}} \mathrm{C} 6$, Biosciences).

\section{RESULT}

\section{Microscopic Examination}

The cytopathic effect (CPE) appear very clear in the FHK-Tcl3.1 cells infected by 50 PFU / $100 \mu \ell$ after 24 hr post infection (Fig. $1 \mathrm{~A}$ ), in addition to there is decreased in the number of CPE in case of added saponin by concentration of $50 \mu \mathrm{g}$ (Fig. 1B) compared to $\mathrm{CPE}$ that appeared in case of EHV-1 alone, from another side there is more decreased in the number of CPE in case of added saponin with concentration $100 \mu \mathrm{g}$ (Fig. $1 \mathrm{C}$ and D).

\section{Staining cells}

After overlaid the cells with $0.8 \%$ agarose the cells were settled with $5 \%$ buffered formaldehyde for 60 min and the agarose layers were expelled then the cells were staining with crystal violet and plaques were checked, it is clear that there is decreased in the number of $\mathrm{CPE}$ in case of added saponin compared to CPE in case of EHV-1 alone (Fig. 2 A, B and C).

\section{Flowcytometric analysis}

EHV-1 infected to FHK-Tcl3.1 used as antigen, and FHK-Tcl3.1 cells alone were used as control for cytometric analysis. By using monoclonal antibody specific to EHV-1(Mahmoud et al., 2013) as first antibody with dilution (1:500) and using Alexa Fluor ${ }^{\circledR} 488$ goat anti-mouse $\operatorname{IgG}(\mathrm{H}+\mathrm{L})$ as a secondary antibody diluted to (1:500), the result was reduction in infection rate to FHK-Tcl3.1 by $55.7 \%$ and $59.2 \%$ in case of added saponin by concentration of $50 \mu \mathrm{g}$ and $100 \mu \mathrm{g}$ compared to EHV-1 alone (Fig.3). 

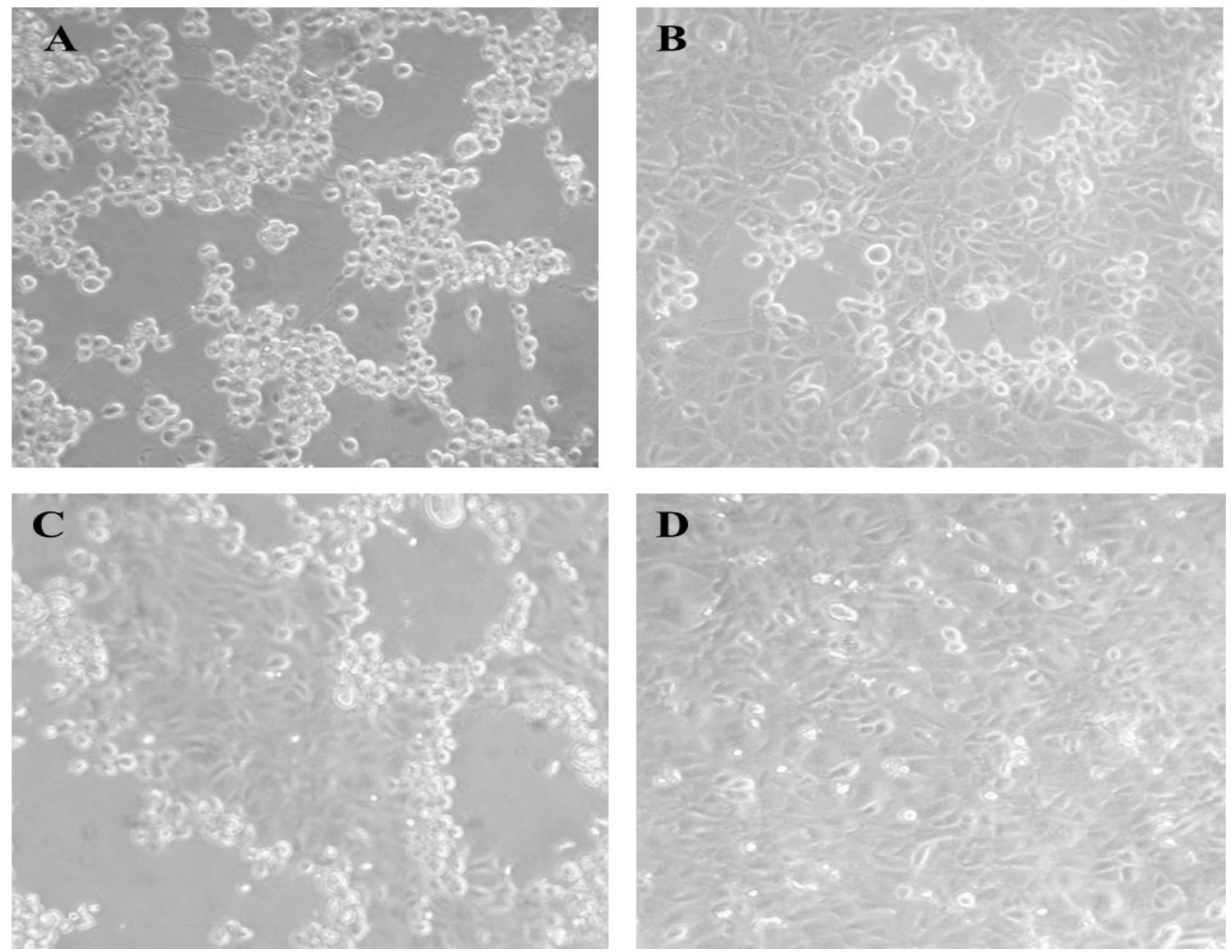

Fig. 1. A and C are microscopic examination of FHK-Tcl.3.1 cells after 24 hours from infection with EHV-1. B and D are cells that treated with saponin by concentration of $(50 \mu \mathrm{g}$ and $100 \mu \mathrm{g})$.
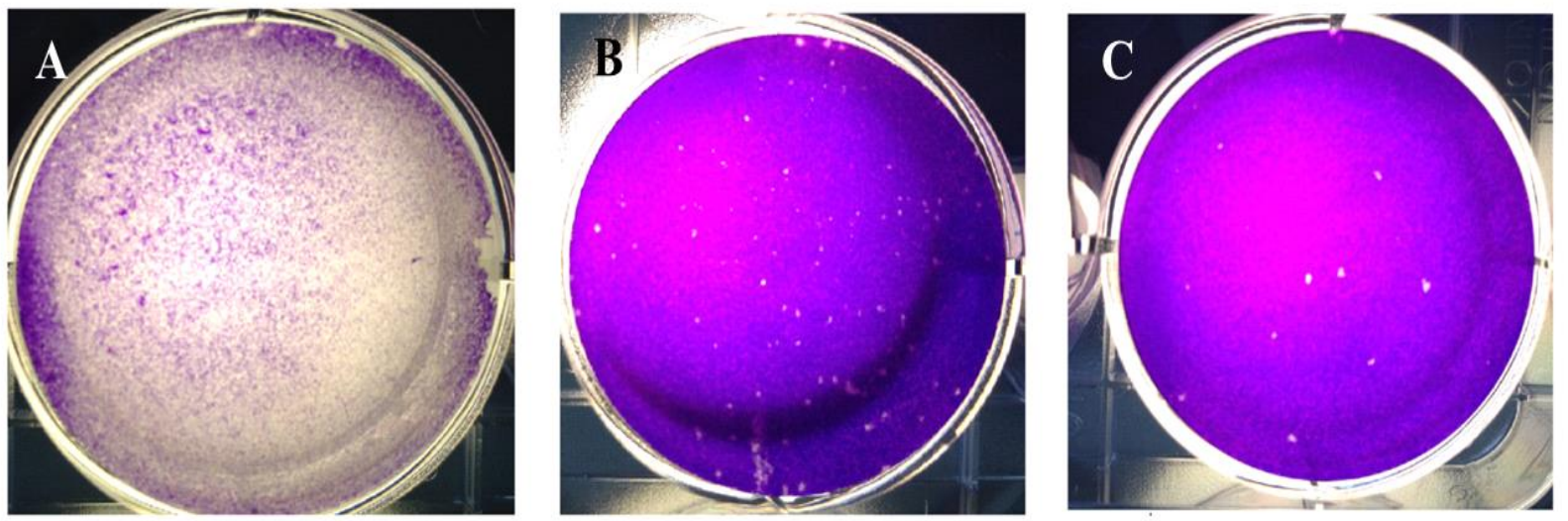

Fig. 2. A is a microscopic examination of stained cells with crystal violet after 24 hours from infection. B and C are microscopic examination of cells infected with EHV-1 which treated with saponin by concentration $(50 \mu \mathrm{g}$ and $100 \mu \mathrm{g}$ ). 

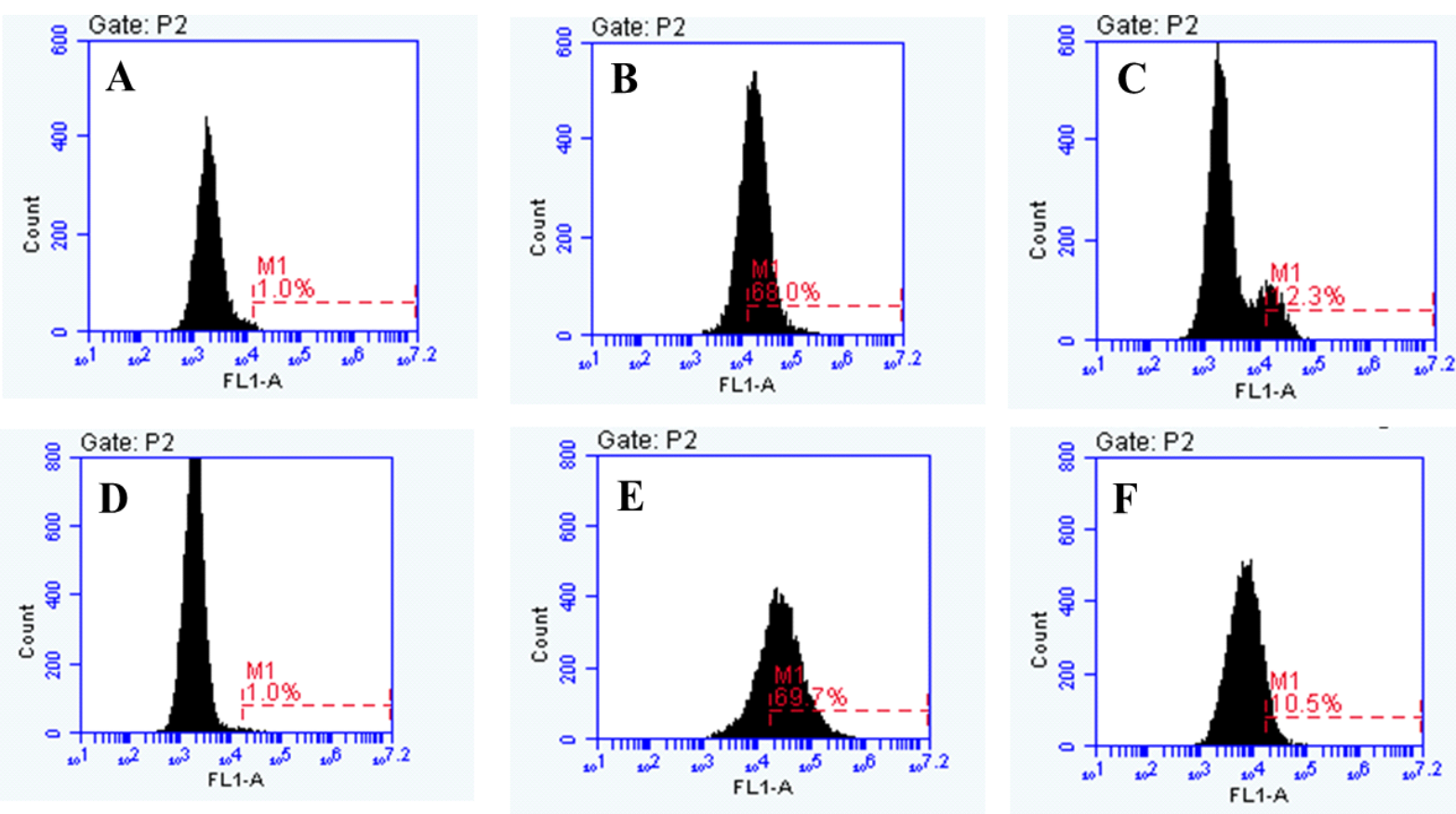

Fig.4. A and D are flowcytometric analysis using FHK-Tcl3.1cells as control without infection. B and E flowcytometric analysis using EHV-1 infected to FHK-Tcl3.1. C and F flowcytometric analysis using EHV-1 and saponin with concentration $(50 \mu \mathrm{g}$ and $100 \mu \mathrm{g})$.

\section{DISCUSSION}

EHV-1 is a relentless infection disease settles after a few weeks, yet EHV-1 caused an industrious infection characterized by latency with chronic reactivations. The treatment of EHV-1 is testing and the result is specifically identified with the seriousness of the neurological deficits in the influenced horse, as no treatment is available, the management of affected animals is directed towards supportive nursing and wholesome care to decreasing CNS inflammation (Pusterla et al., 2009).

Numerous steeds are latently infected with EHV-1 and reactivation of the infection can happen under stress, where upon latently infected carriers begin to shed infection virus that may spread to in contact stallions (Pusterla et al., 2009-2010).

Herbal pharmaceuticals and purged characteristic items give a rich asset to novel antiviral medication improvement (Liang-Tzung, 2014). In this study, we try to use the antiviral compound from natural products and it is action against EHV-1 by using flowcytometric analysis and virus neutralization test which is considered as the standard test for a laboratory diagnosis of EHV-1 infection, we utilized it to determine the effective of saponin in the reduction of EHV-1 infection to cells in vitro, it is appear that more than fifty percent was reduction in infection rate of virus to cells after $24 \mathrm{hr}$ with concentration between 50-100 $\mu \mathrm{g}$. The mechanism of this compound may be due to the interact with the life cycle of virus inside the cells or maybe due to interact with the methods that used by viruses to enter cells, in addition to this compound was chartered by anticancer activity (Mostafa et al., 2017). More study well be needed to clarify the role of the compound as antiviral in the future for treatment the viral infection, it can be utilized as a part without bounds to treatment the viral infection, more investigation it will be expected to decide the method for it is activity in viral pathogenesis in vivo.

\section{CONCLUSION}

This saponin compound was active in vitro as antiviral, it was reduction in the infection rate of EHV-1 to cells, so it may be used as antiviral drugs in the future for treatment the viral infection, more study will be needed to determine the effective of this compound in vivo, this to be complete the clear the action of this compound in both cells and virus.

\section{ACKNOWLEDGEMENTS}

Hassan Y.A.M. received financial support in the form of post doctor scholarship from the Egyptian government. 


\section{REFERENCES}

Abdelrahman, M.; Hirata, S.; Ito, S.; Yamauchi, N. and Shigyo, M. (2014): Compartmentation and localization of bioactive metabolites in different organs of Allium roylei. Biosci. Biotechnol. Biochem., 7: 1112-1122.

Abdelrahman, M.; Abdel-Motaal, F.; El-Sayed, M.; Jogaiah, S.; Shigyo, M.; Ito, S. and Tran, L.S. (2016): Dissection of Trichoderma longibrachiatum induced-defense in onion (Allium cepa L.) against Fusarium oxysporum f. sp. cepa by target metabolite profiling. Plant Sci., 246: 128-138.

Allen, G.P. and Bryans, J.T. (1986): Molecular epizootiology, pathogenesis and prophylaxis of equine herpesvirus-1 infections. Prog. Vet. Microbiol. Immunol., 2: 78-144.

Andoh, K.; Kai, K.; Matsumura, T. and Maeda, K. (2009): Further development of an equine cell line that can be propagated over 100 times. $J$. Equine Sci., 20: 11-14.

Caruso, G.; Conti, S.; Villari, G.; Borrelli, C.; Melchionna, G.; Minutolo, M.; Russo, G. and Amalfitano, C. (2014): Effects of transplanting time and plant density on yield, quality and antioxidant content of onion (Allium cepa L.) in southern Italy. Sci. Hortic., 166: 111-120.

Edington, N.; Bridges, C.G. and Patel, J.R. (1986): Endothelial cell infection and thrombosis in paralysis caused by equid herpesvirus- 1: equine stroke. Arch. Virol., 90: 111-124.

Eisenberg, D.M.; Kessler, R.C. and Van Rompay (2001): Perceptions about complementary therapies relative to conventional therapies among adults who use both: results from a national survey. Ann. Intern. Med., 135: 344351.

Fritsch, R.M.; Blattner, F.R. and Gurushidze, M. (2010): New classification of Allium L. subg. Melanocrommyum (Webb and Berthel) Rouy (Alliaceae) based on molecular and morphological characters. Phyton, 49:145220.

Gibson, J.S.; Slater, J.D.; Awan, A.R. and Field, H.J. (1992): Pathogenesis of equine herpesvirus-1 in specific pathogen-free foals: primary and secondary infections and reactivation. Arch. Virol., 123: 351-366.

Heldens, J.G.M.; Hannant, D.; Cullinane, A.A.; Prendergast, M.J.; Mumford, J.A.; Nelly, M.; Kydd, J.H.; Weststrate, M.W. and van den Hoven, R. (2001): Clinical and virological evaluation of the efficacy of an inactivated EHV1 and EHV4 whole virus vaccine (Duvaxyn EHV1,4). Vaccination/challenge experiments in foals and pregnant mares. Vaccine, 19: 4307-4317.

Huang, Kao-Jean; Yang, Yu-Ching, Lin, Yee-Shin, Liu, Hsiao-Sheng and Yeh, Trai-Ming (2005):
Flow Cytometric Determination for Dengue Virus-Infected Cells: Its Application for Antibody-Dependent Enhancement Study. Dengue Bulletin, 29:142-150.

Kamenetsky, R. and Rabinowitch, H.D. (2006): The Genus Allium: a developmental and horticultural analysis. Hortic. Rev., 32:329378.

Kydd, J.H.; Smith, K.C.; Hannant, D.; Livesay, G.J. and Mumford, J.A. (1994): Distribution of equid herpesvirus-1 (EHV-1) in the respiratory tract of ponies: implications for vaccinationstrategies. Equine Vet. J., 26: 466469.

Liang-Tzung Lin, Wen-Chan Hsu, and Chun-Ching Lin. (2014): Antiviral Natural Products and Herbal Medicines. J. Tradit Complement Med., 41: 24-35.

Maeda, K.; Yasumoto, S.; Tsuruda, A., Andoh, K.; Kai, K.; Otoi, T. and Matsumura, T. (2007): Establishment of a novel equine cell line for isolation and propagation of equine herpesviruses. J. Vet. Med. Sci., 69: 989-991.

Mahmoud, H.Y.; Andoh, K.; Hattori, S.; Terada, Y.; Noguchi, K.; Shimoda, H. and Maeda, K. (2013): Characterization of Glycoproteins in Equine Herpesvirus-1. J. Vet. Med. Sci., 75: 1317-21.

Matsumura, T.; Sugiura, T.; Imagawa, H.; Fukunaga, Y. and Kamada, M. (1992): Epizootiological aspects of type 1 and type 4 equine herpesvirus infections among horse populations. J. Vet. Med. Sci., 54: 207-211.

McSharry, J.J. (1994): Uses of flow cytometry in virology. Clin. Microbiol. Rev., 4: 576-604.

Mostafa Abdelrahman; Hassan Y.A.H. Mahmoud, Magdi El-Sayed and Shuhei Tanaka. (2017): Isolation and characterization of Cepa2, a natural alliospiroside A,from shallot (Allium cepa L. Aggregatum group) with anticancer activity. Plant Physiol. Biochem., 116: 167173.

Mostafa, A.; Sudisha, J.; El-Sayed, M.; Ito, S-I.; Ikeda, T.; Yamauchi, N. and Shigyo, M. (2013): Aginoside saponin, a potent antifungal compound, and secondary metabolite analyses from Allium nigrum L. Phytochem. Lett., 6: 274-280.

Patel, J.R.; Edington, N. and Mumford, J.A. (1982): Variation in cellular tropism between isolates of equine herpesvirus-1 in foals. Arch. Virol., 74: $41-51$

Pusterla, N.; David Wilson, W.; Madigan, J.E. and Ferraro, G.L. (2009): Equine herpesvirus-1 myeloencephalopathy: a review of recent developments. Vet. J., 180: 279-89.

Pusterla, N.; Hussey, S.B.; Mapes, S.; Johnson, C.; Collier, J.R.; Hill, J.; Lunn, D.P. and Wilson, W.D. (2010): Molecular investigation of the viral kinetics of equine herpesvirus-1 in blood and nasal secretions of horses after 
corticosteroid-induced recrudescence of latent infection. J. Vet. Intern. Med., 24: 1153-1157.

Sabine, M.; Robertson, G.R. and Whalley, J.M. (1981): Differentiation of sub-types of equine herpesvirus 1 by restriction endonuclease analysis. Aust. Vet. J., 57: 148-149.

Slader, C.A.; Reddel, H.K.; Jenkins, C.R.; Armour, C.L. and Bosnic-Anticevich, S.Z. (2006): Complementary and alternative medicine use in asthma, Respiratory, 4: 373-387.

Studdert, M.J.; Simpson, T. and Roizman, B. (1981): Differentiation of respiratory and abortigenic isolates of equine herpesvirus 1 by restriction endonucleases. Science, 214: 562-564.

Turtinen, L.W.; Allen, G.P.; Darlington, R.W. and Bryans, J.T. (1981): Serological and molecular comparisons of several equine herpesvirus type 1 strains. Am. J. Vet. Res., 42: 2099-2104.

Van der Meulen, K.; Caij, B.; Pensaert, M. and Nauwynck, H. (2006): Absence of viral envelope proteins in equine herpesvirus 1infected blood mononuclear cells during cellassociated viremia. Vet. Microbiol., 113: 265-273.

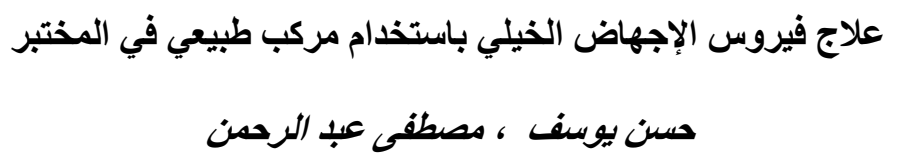

E-mail: hayvet2002@yahoo.com Assiut University web-site: www.aun.edu.eg

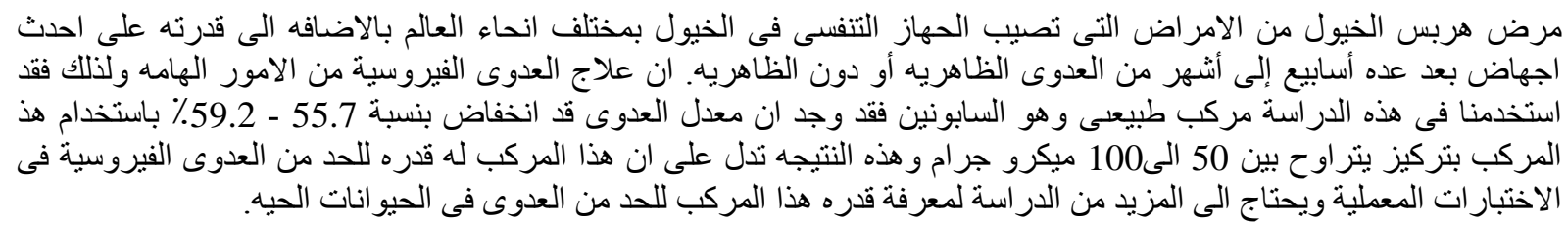

